\title{
CORRECTION
}

\section{Correction: Hopefully devoted to Q: targeting glutamine addiction in cancer}

Emma R. Still ${ }^{1}$ and Mariia O. Yuneva ${ }^{1}$

British Journal of Cancer (2019) 120:957; https://doi.org/10.1038/s41416-019-0432-7

Correction to: British Journal of Cancer (2017) 116:1375-1381; https://doi.org/10.1038/bjc.2017.113; http://www.bjcancer.com; published online: 25 April 2017

This article was originally published under a CC BY NC SA License, but has now been made available under a CC BY 4.0 License.

\begin{abstract}
Open Access This article is licensed under a Creative Commons Attribution 4.0 International License, which permits use, sharing, BY Attribution 4.0 International License, which permits use, sharing,
adaptation, distribution and reproduction in any medium or format, as long as you give appropriate credit to the original author(s) and the source, provide a link to the Creative Commons license, and indicate if changes were made. The images or other third party material in this article are included in the article's Creative Commons license, unless indicated otherwise in a credit line to the material. If material is not included in the article's Creative Commons license and your intended use is not permitted by statutory regulation or exceeds the permitted use, you will need to obtain permission directly from the copyright holder. To view a copy of this license, visit http://creativecommons. org/licenses/by/4.0/.
\end{abstract}

(c) The Author(s) 2019

${ }^{1}$ Oncogenes and Tumour Metabolism Laboratory, The Francis Crick Institute, 1 Midland Road, London NW1 1AT, UK Correspondence: M. O. Yuneva (Mariia.Yuneva@crick.ac.uk)

Published online: 14 March 2019 